\title{
Branding in Urban Discourse Space: Region's Identity as Attraction Factor
}

\author{
Elina Novikova, Vera Mityagina, Anna Gureeva*, and Tatyana Makhortova \\ Translation Studies Department, Volgograd State University, Volgograd, Russia
}

\begin{abstract}
The research is focused on branding as a communicative process and aimed at defining the region's identity role in provision of its tourist attraction. Linguistic analysis of the branding process is concentrated on optimization of language means and urban semiosis quality. City's identity is viewed as a complex of exterior and other markers, building its complex image and playing an initial role in city's branding. The aim of territory' branding is to present the uniqueness of a certain region and its competitiveness. A city is a complicated multilayer communicative formation that creates a special type of discourse around itself - urban discourse. The space of this discourse is determined by such textual phenomena as a text-city, an urban text and a text about a city. The authors outline the role of naming in city branding and consider a great importance of a city's identity in creating a text content aimed at increasing attraction of a city as a tourist object. City's identity allows one to understand its uniqueness and mental representation by a representative of its "own" and "foreign" cultures and optimize branding strategies with the aim to fix positive images of a city and attractive image of a global-centred and locally original territory.
\end{abstract}

\section{Introduction}

Urban research is actively conducted by the representatives of diverse schools of scientific fields: philosophers, social scientists, marketing experts, political analysts, and linguists. Whereas, a city's hypertextual space is a complex of symbols, signs, images, there is an interest and necessity of a linguistic view on urban discourse aimed at determining language instruments and mechanisms of a city's linguosemiotics verbalized in place branding. In the modern globalised society, the competitive struggle among territories, first of all, among cities, becomes more evident. Global requirements for regions' economic attraction have changed and promote local actuation of marketing activity, and place branding. Place marketing is closely connected with all aspects of branding in its communicative sense as a process, and the results of linguistic studies of branding phenomenon can promote to solve real economic tasks. The goal of branding is to make a certain region be viewed as unique and predominantly competitive. An important role to achieve efficient branding, therewith, is played by a region's identity that helps to create attractive images and build a complex positive image. The subject for this study is the city's identity as a complex of exterior architectural, climate, social, cultural and other markers that construct its reputation and work for the city's branding.

\subsection{City's identity as a base of brand building}

S. Anholt asserts Kotler's position to be prophetic, as "no place, it seems, can now think of surviving, let alone prospering, unless it knows how to wield the weapons of business" [1].

The history of civilization shows that places always exist in competitive relations, in a struggle for residents, consumers, visitors, investors, etc. [2].

A complex image of a place is formed due to three interrelated factors: external appearance (a complex of visual signs in a city), a language (a complex of texts about a place, inside a place), and expectations (a complex of experience, expectations and images of a place).

A complex image is built up, first of all, basing on a region's identity, a combination of expectations, images and events of a certain territorial entity that forms its complex image on the basis of its identity. It is necessary to change the components of a territory's identity in order to change its complex image.

N.S. Dyagileva differentiates the notions of "urban identity", "identity of a city" and "identity to a city". The scientist notes that "in the first case, we talk about a city residents' vision of themselves as residents of this (their) city, in particular; in the second case, we talk about a vision of a city where its essence, features, similarities and differences with other cities are described... "identity to a city" is a psychological construct, a part of

* Corresponding author: gureeva@ volsu.ru 
a person's individual identity, when a city is viewed as a context of an person's individual biography" [3].

Identity of a city is built up due to a combination of factors: constant ones, which are connected to its history, location, natural and climatic peculiarities and changeable factors such as infrastructure, influencing its exterior appearance, citizens, economic development, political landscape, cultural traditions, etc.

Any territorial entity, first of all, a city, as a resource of knowledge, plays a role of a magnet for tourism. A city is a kind of a centre attracting tourists which combines local national and cultural dominants and elements of globally oriented leisure activities. From year to year, city cultural tourism gathers pace and is performed within multiple international, all-Russia and regional programmes. A city, due to its transport infrastructure, intercultural relations, communications, etc., has several channels to interact with "exterior" world, that is why importance is being increasingly attached to socio-economic and marketing strategies in cities' development, because this type of tourism balances on the edge of economic efficiency and sociocultural relevance. City tourism, as well as, intercultural city tourism, is one of the most ancient form of travelling and, for today, integrates various discourses and discourse practices: business discourse, cultural discourse, administrative discourse, and etc., that argues for the fact that city tourism obtains the features of other discourses and, without any doubt, requires a more thorough concern about its specifics within different research views.

A city is an identity card of a region/country, a mirror of the character, mentality, and soul of a certain nation. The German representatives of formal sociology F. Tennis [4] and G. Zimmel [5] supposed that a city fulfils a backbone function in the national culture and noted that a city's ability to translate to its society the processes that occur inside it, such as, crisis process and modern society's decline, levelling-out the values of traditional culture, globalization, and etc.

A city is a complicated multilayer, multitexture communicative formation that creates a special type of discourse around itself. A city as a text is increasingly becoming an object of linguistic research. E.A. Yakovleva introduces the notion of "urban text" together with "urban studies" as an independent discipline on urban communicative processes [6]. Urban communication creates a certain discourse - a city, urban one, a discourse of a "global city's community", etc. N.V. Lyubimova counts in favour of an emerging city discourse, which, she thinks, "is a mirror for reflecting and interacting trends dominating in semiotic systems that are connected with urban life, starting with architecture and clothes fashion up to language» [7]. Due to the careful attention of the representatives of various sciences to the urban studies notion, a city discourse reveals its interdisciplinary nature and determines the priority to use the term "urban discourse".

\subsubsection{Discourse paradigm of urban discourse}

Urban discourse shows tendency to poly- and inderdiscoursivity, because it reveals the presence of multiple autonomous discursive practices. Inder- and polydiscoursivity of urban discourse is formed due to its heterogeneity and polyphony, which are the integrative features of the interrelated types of discourse involved in a city's communicative space. Here, a lot of institutional and person-centred discursive practices echo: tourism, city-planning, cultural, sports, mass media, educational, architectural, economic, administrative, and other types of discourses. That is obvious, that the tonality of each of the above-mentioned discourses, in focus of a city discourse, is a marker of a new construction of interaction processes connected with the change of value orientation and living standards upgrade. Discursive practices implemented in city communication, in total, build up a field structure for an urban discourse, gives a possibility to cross with other types of discourse. The core of an urban discourse field structure generates a city discourse itself, where its residents (citizens) act as its participants establishing personal and status-centred relations. The periphery of urban discourse is formed due to other institutional discourses integrated, in a particular way, into a city's discourse space.

Each of the above-mentioned and other discourses is a channel which forms an urban identity and its brand; this channel has a certain ray of verbal and nonverbal means and tools used in marketing and advertising technologies. Herewith, an important constituent of any discourse is a text, in its wide sense, where a text is a city itself as a comprehensive semiotic system and, in a traditional linguistic understanding of a text as a verbal presentation of a thought. Moreover, that seems logical to differentiate a traditional understanding of a text and a thorough understanding of such phenomena as "urban text", "text in a city" and "text about a city". Yu.M. Lotman writes about a city as a text and views it as a complex of texts and codes which are "differently structured and heterogeneous, belonging to different languages and different levels" [8]. That is a complicated semiotic system of images and mental representations, reflecting a sociocultural regionally determined worldview. E.A. Yakovleva understands a city as "all forms of human's activity within a city written as a text and an element of a city's dialogue included into various types of communication" [6].

The elements of an urban text are city's objects, symbolic places, fixed in visual and verbal signs, symbols, archetypes, stereotypes, myths, local stories, etc. A text-city, in its turn, creates a special lexicon which characterizes this territorial entity:

- names of streets, buildings, monuments, prominent persons, bridges, shops and etc. (toponyms, urbanyms, personal names),

- signposts,

- commemorative plaques,

- advertising signboards and panels.

We should note that verbal peculiarity of an urban text, especially in case of large metropolises, is its multilinguality, because in modern globalised world with 
open borders and tendencies to transcultural communication the factor of multilinguality is a marker of a modern mobile city.

Texts about a city are the largest layer of semiotic codes that form and reflect a city's identity. What is meant here is polygenre and polyfunctional system of text material translated via various channels of oral, written and computer-mediated communication. These are the texts that reveal what a city "breathes" with, which expectations and associations it evokes for its citizens and guests, how it presents itself in global-local and cross-cultural dimensions and which dominants lay in its basis of its territorial branding. The constituents of "urban text", "text in a city" and "text about a city" within a discourse paradigm of urban discourse are presented in Table 1:

Table 1 City's presentation elements within urban discourse paradigm.

\begin{tabular}{|c|c|c|c|}
\hline $\begin{array}{c}\text { Types of } \\
\text { discourses } \\
\text { within } \\
\text { urban } \\
\text { discourse }\end{array}$ & Text-city & Urban text & $\begin{array}{c}\text { Text about a } \\
\text { city }\end{array}$ \\
\hline city & $\begin{array}{l}\text { a complex } \\
\text { of social } \\
\text { symbols of } \\
\text { a city, } \\
\text { developed } \\
\text { by citizens } \\
\text { during their } \\
\text { life } \\
\text { experience: } \\
\text { ways, } \\
\text { districts, } \\
\text { regions, } \\
\text { etc. }\end{array}$ & \multirow[t]{4}{*}{$\begin{array}{l}\text { signs and } \\
\text { markings, } \\
\text { advertisem } \\
\text { ents, } \\
\text { advertising } \\
\text { banners, } \\
\text { address } \\
\text { plaques and } \\
\text { home signs, } \\
\text { commemor } \\
\text { ative } \\
\text { plaques, } \\
\text { plates, } \\
\text { signposts, } \\
\text { pictures, } \\
\text { photos }\end{array}$} & $\begin{array}{l}\text { a complex of } \\
\text { texts }\end{array}$ \\
\hline historical & $\begin{array}{l}\text { memorable } \\
\text { places }\end{array}$ & & $\begin{array}{l}\text { scientific } \\
\text { publications, } \\
\text { popular science } \\
\text { literature, } \\
\text { information and } \\
\text { reference, } \\
\text { encyclopedic, } \\
\text { biographical } \\
\text { publications, } \\
\text { archival data }\end{array}$ \\
\hline architectural & $\begin{array}{l}\text { architectural } \\
\text { monuments }\end{array}$ & & $\begin{array}{l}\text { scientific } \\
\text { publications, } \\
\text { popular science } \\
\text { literature, } \\
\text { information and } \\
\text { reference, } \\
\text { encyclopedic, } \\
\text { biographical } \\
\text { publications }\end{array}$ \\
\hline educational & $\begin{array}{l}\text { institutions } \\
\text { of higher } \\
\text { education, } \\
\text { educational } \\
\text { institutions, }\end{array}$ & & $\begin{array}{l}\text { scientific } \\
\text { publications, } \\
\text { popular science } \\
\text { literature, }\end{array}$ \\
\hline
\end{tabular}

\begin{tabular}{|c|c|c|c|}
\hline $\begin{array}{c}\text { Types of } \\
\text { discourses } \\
\text { within } \\
\text { urban } \\
\text { discourse }\end{array}$ & Text-city & Urban text & $\begin{array}{c}\text { Text about a } \\
\text { city }\end{array}$ \\
\hline & clubs & & $\begin{array}{l}\text { information and } \\
\text { reference, } \\
\text { information, } \\
\text { encyclopedic, } \\
\text { biographical } \\
\text { publications, } \\
\text { PR-texts, } \\
\text { websites of } \\
\text { educational } \\
\text { institutions }\end{array}$ \\
\hline sports & $\begin{array}{l}\text { sports } \\
\text { facilities, } \\
\text { sports } \\
\text { schools }\end{array}$ & & $\begin{array}{l}\text { scientific } \\
\text { publications, } \\
\text { popular science } \\
\text { literature, } \\
\text { information and } \\
\text { reference, } \\
\text { information, } \\
\text { encyclopedic, } \\
\text { biographical } \\
\text { publications, } \\
\text { advertising } \\
\text { publications, } \\
\text { websites of } \\
\text { sports } \\
\text { institutions and } \\
\text { sports } \\
\text { organizations }\end{array}$ \\
\hline media & $\begin{array}{l}\text { mass media } \\
\text { institutions }\end{array}$ & & $\begin{array}{l}\text { mass media } \\
\text { texts }\end{array}$ \\
\hline cultural & $\begin{array}{l}\text { museums, } \\
\text { theatres }\end{array}$ & & $\begin{array}{l}\text { scientific } \\
\text { publications, } \\
\text { popular science } \\
\text { literature, } \\
\text { information and } \\
\text { reference, } \\
\text { information, } \\
\text { encyclopedic, } \\
\text { biographical } \\
\text { publications, } \\
\text { advertising } \\
\text { publications, } \\
\text { websites of } \\
\text { museums / } \\
\text { theatres / art } \\
\text { galleries }\end{array}$ \\
\hline $\begin{array}{c}\text { environme } \\
\text { ntal }\end{array}$ & $\begin{array}{l}\text { parks, } \\
\text { nature } \\
\text { reserves }\end{array}$ & & $\begin{array}{l}\text { scientific } \\
\text { publications, } \\
\text { popular science } \\
\text { literature, } \\
\text { information and } \\
\text { reference, } \\
\text { information, } \\
\text { encyclopedic, } \\
\text { biographical } \\
\text { publications, } \\
\text { advertising }\end{array}$ \\
\hline
\end{tabular}




\begin{tabular}{|c|c|c|c|}
\hline $\begin{array}{c}\text { Types of } \\
\text { discourses } \\
\text { within } \\
\text { urban } \\
\text { discourse }\end{array}$ & Text-city & Urban text & $\begin{array}{c}\text { Text about a } \\
\text { city }\end{array}$ \\
\hline & & & publications \\
\hline $\begin{array}{l}\text { Administra } \\
\text {-tive }\end{array}$ & $\begin{array}{l}\text { authorities, } \\
\text { social } \\
\text { services, } \\
\text { migration } \\
\text { agencies, } \\
\text { administrat } \\
\text { ion offices, } \\
\text { housing } \\
\text { and public } \\
\text { utilities } \\
\text { services }\end{array}$ & & $\begin{array}{l}\text { information and } \\
\text { reference, } \\
\text { information, } \\
\text { encyclopedic, } \\
\text { biographical } \\
\text { and marketing } \\
\text { publications, } \\
\text { websites of } \\
\text { administrative } \\
\text { institutions, } \\
\text { official } \\
\text { documents }\end{array}$ \\
\hline tourism & $\begin{array}{l}\text { travel } \\
\text { agencies, } \\
\text { sightseeing } \\
\text { tour } \\
\text { accompany } \\
\text { ing }\end{array}$ & & $\begin{array}{l}\text { information, } \\
\text { marketing, } \\
\text { information } \\
\text { and advertising } \\
\text { publications, } \\
\text { guides, web } \\
\text { portals, } \\
\text { promotional } \\
\text { materials }\end{array}$ \\
\hline art & $\begin{array}{l}\text { musical } \\
\text { compositio } \\
\text { ns, works } \\
\text { of art, } \\
\text { painting } \\
\text { specimens }\end{array}$ & & 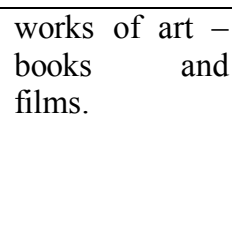 \\
\hline religious & $\begin{array}{l}\text { cathedrals, } \\
\text { religious } \\
\text { objects }\end{array}$ & & religious texts \\
\hline translation & $\begin{array}{l}\text { translation } \\
\text { agencies, } \\
\text { companies, } \\
\text { translators } \\
\text { and } \\
\text { interpreters }\end{array}$ & & $\begin{array}{l}\text { a diversity of } \\
\text { translated texts }\end{array}$ \\
\hline $\begin{array}{c}\text { PR, } \\
\text { marketing, } \\
\text { advertising }\end{array}$ & $\begin{array}{l}\text { advertising } \\
\text { signboards } \\
\text { and panels, } \\
\text { banners, } \\
\text { fliers }\end{array}$ & & $\begin{array}{l}\text { marketing and } \\
\text { PR } \\
\text { publications, } \\
\text { advertising } \\
\text { texts }\end{array}$ \\
\hline scientific & $\begin{array}{l}\text { scientific } \\
\text { unions, } \\
\text { research } \\
\text { institutions }\end{array}$ & & $\begin{array}{l}\text { scientific } \\
\text { publications, } \\
\text { popular science } \\
\text { literature, } \\
\text { encyclopedic, } \\
\text { biographical } \\
\text { publications } \\
\text { (articles, } \\
\text { monographs, } \\
\text { thesis works, } \\
\text { etc.) }\end{array}$ \\
\hline business & business & & Business letters, \\
\hline
\end{tabular}

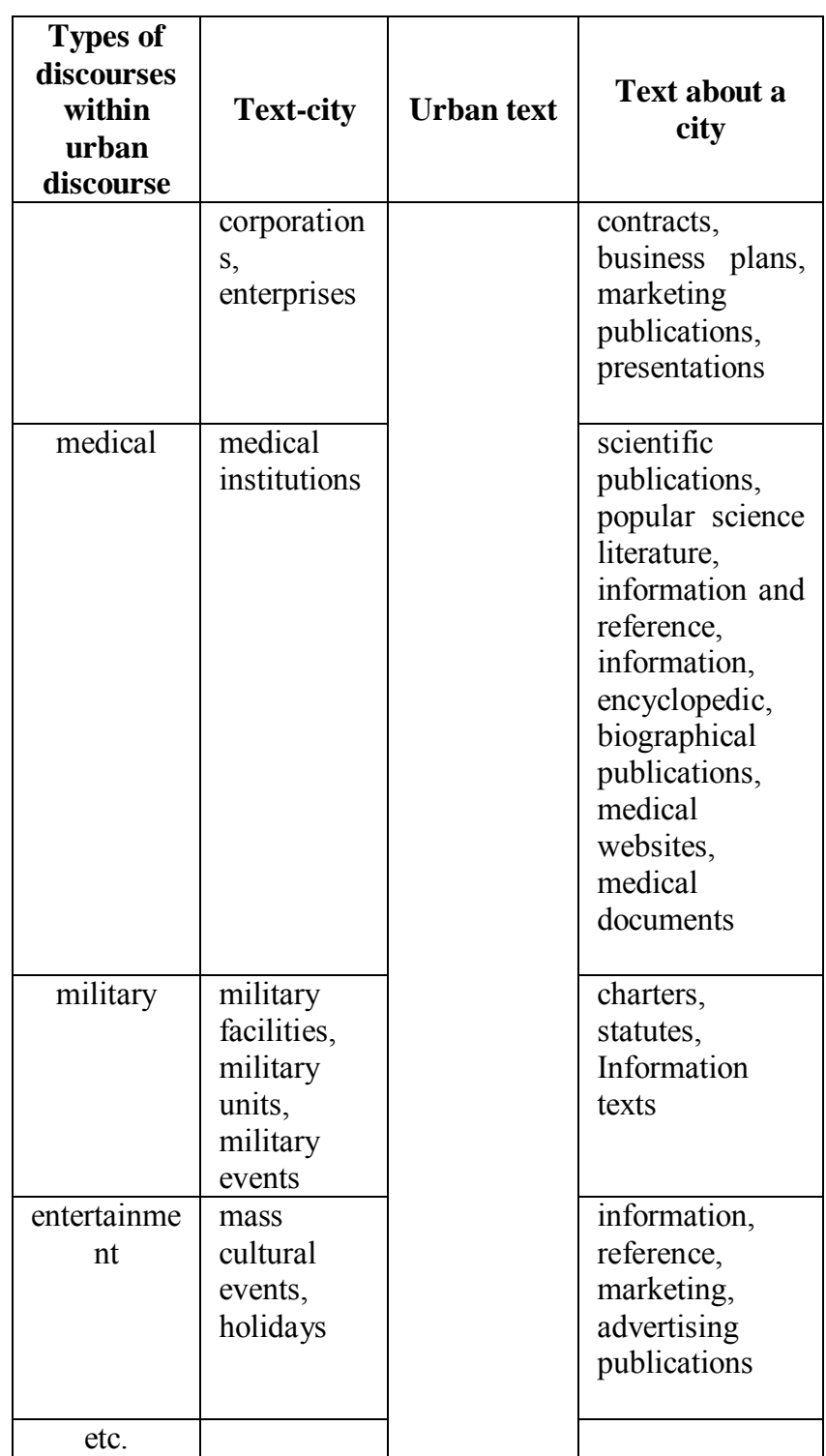

Interaction within textual communication revealing a city's identity, which, in its turn, influences the creation of images, and, finally, brands can be presented in the following way:

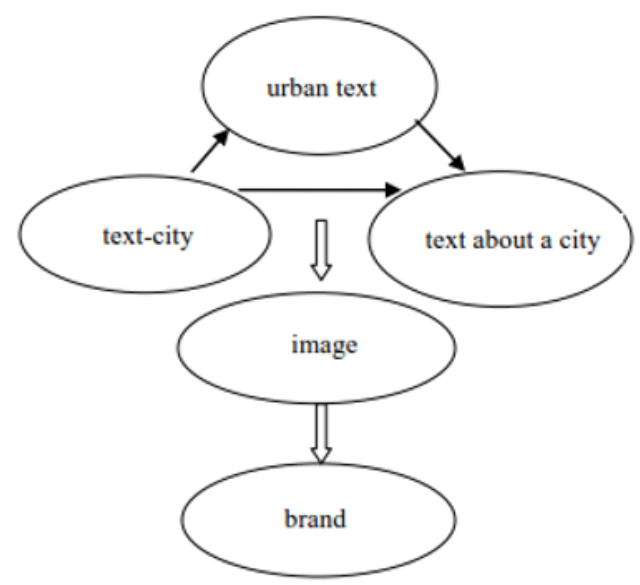

Fig. 1 Interaction within textual communication: brand creation. 


\section{Brand as place's identity factor}

Brand's visual identification is realized, first of all, in its shape, both graphic and language ones. To build up a place's touristic brand, various technologies are applied, verbal and visual symbols are created and implemented. A place's brand is an indicator of its recognition, an instrument that helps to present it on the regional, country and, even, world level [9]. A city's brand-name, as well as, names of a city's infrastructure objects as a combination of semiotic codes must have a number of characteristics: unity and pragmatic value, well-built visuality and virtuality, emotional breadth, recognition and return on investment. In view of this, it is worth paying special attention to the issue of naming as a linguistic problem in the urban brand creation system with the use of various genres of the website of the city of Volgograd [http://www.volgadmin.ru/d/list/news/adm $\operatorname{vlg}]$.

The front content of the web portal of Volgograd combines the following headings: About the City $(O$ городе); City's Authorities (Органь власти); Services (Услуги); Documents (Документы); Open Data (Открытые данные); Feedback (Обратная связь); World Cup 2018 (ЧM 2018); Transport in Volgograd (Транспорт Волгограда); Social Infrastructure (Социальная сфера); Economics and Finance (Экономика и финансы); Urban Environment (Городская среда); Patriotic Movement (Патриотическое движение). The headings Strategy of Volgograd 2030 (Стратегия Волгограда 2030) and Investment Plan (Инвестиционная карта) are presented separately.

The names of the headings let to get a first impression about the city as an economic region; there is a focus on its event and activity potential and patriotic education.

The industrial and economic constituent of the city's development is presented in informative and information and reference texts about the city and its history:

Волгоград, благодаря своему выгодному транспортно-географическому положению $u$ высокому промышленному потенциалу, выполняет важные стратегические функции в социальноэкономическом развитии Юга России. (Volgograd, due to its advantageous transport and geographical location and high industrial potential performs important strategic functions in social and economic development of the South of Russia).

The heading About the City ( $O$ ropode) includes subheadings History (история), Tourism (туризм), Honorary citizens (лица города), Twin-cities (городаnобратимы), Partner cities (города-партнеры). The volume of texts under this heading is not big, and presents a genre of informative texts with dominating cognitive information. They briefly tell about the city's touristic potential within military and historical spectrum:

Город-герой навсегда вписал свое имя в историю нашей Родинь - победа в Сталинградской битве изменила весь ход Второй Мировой войны. (The hero-city has forever marked a place for itself in the history books of our Motherland - the victory in the Battle of Stalingrad changed the outcome of the Second World War).

Здесь находится главная высота России Мамаев Курган и скульптурная композиция «Родинамать зовет!», признанной одним из семи чудес России, уникальный музей-панорама «Сталинградская битва», Дом Павлова и многие другие памятные места военной истории. (Here is the main height of Russia - Mamaev Hill and the sculptural composition "Mother-Russia calls!", ranked among the seven wonders of Russia, a unique Panorama-Museum "The Stalingrad Battle", The Pavlov's House and many other memorable places of military history).

This heading also presents brief information on the city's honorary citizens, famous Russian politicians, public figures, people of art, athletes, and military service men.

Most thorough information is provided by the heading World Cup 2018 dealing with preparations for the World Cup in the city, the most interesting city's attractions and its history.

Волгоград - центр перекрёстка цивилизаций. Именно здесь, по мнению историков, располагалась столица Золотой Орды Сарай-Берке и проходившие через нее важнейтие торговые пути. (Volgograd is a center of civilizations' intersection. Right here, according to historians, Saray-Berke - the capital of the Golden Horde, and important trade routes passing through it were located).

Волгоград - по-настоящему спортивный город. На летних Олимпиадах наши спортсмень завоевали десятки золотых наград. Волгоград - город спортивньх побед и достижений. (Volgograd is a real sports city. During the Summer Olympic Games our athletes won dozens of gold medals. Volgograd is a city of sports achievements and victory).

Among the texts presented in the website, the dominance belongs to informative texts in official style which almost do not present any advertising elements or figures of speech. Even in the description of the city's attractions statistic data prevail, for example:

В Волгограде работают 5 музеев, 8 театров, Центральный конщертный зал, художественные галереи, ичирк, планетарий, Двореи спорта, 4 парка отдыха, а также существует 190 памятников истории, 18 памятников монументального искусства, 304 памятника архитектуры. (Volgograd is home to 5 museums, 8 theatres, the Central Concert Hall, art galleries, circus, planetarium, the House of Sports, 4 recreational parks, and also 190 historical monuments, 18 monuments of monumental art, 304 architectural monuments).

The analysis of the text content of the city's web portal let talk about building up the city's branding on the base of the most important events, both historic and modern ones. The historic events include the events taken place during the Russian Civil War in 1918-1920, the Battle of Stalingrad in 1942-1943, and the construction of the Volga-Don Shipping Canal in 1952. 
- Во время Гражданской войны (1918-1920 г2.) в Царицыне происходили ожсесточённые бои. С 1920 2. Царицын - иентр Царицынской губернии. В 1925 г. город был переименован в Сталинград. (During the Russian Civil War (1918-1920), Tsaritsyn was an arena of fierce battling. Since 1920, Tsaritsyn was a center of Tsaritsyn guberniya. In 1920, the city was renamed into Stalingrad).

- Наш славный город был полностью разрушен в годы второй мировой войны. Но сразу же после войны он восстал из пепла, как легендарная птища Феникс. В 1961 году из Сталинграда город-герой был переименован в Волгоград. (Our glorious city was completely destroyed during the Second World War. But right after the war, it rose from the ashes like legendary Phoenix).

Among the important modern events are large-scale activities such as international forums, where Volgograd is presented as a social and political center, or international sports competitions - World Cup 2018, on the eve of which the city is undergoing innovation process which is shown in the news feed, for example:

- Во всех районах Волгограда появились стенды с проектами благоустройства общественных терpumopuŭ. (Stands with provision of urban amenities projects have been installed in all districts of Volgograd).

- В Волгоградской области во время ЧМ-2018 будуm работать 1196 волонтеров Оргкомитета. (1196 volunteers from the Organizing Committee will work in the Volgograd region during the World Cup 2018).

- Во время футбольных матчей в Волгограде будут организованы пешеходные зоны, бесплатные парковки и новые разворотные кольца горэлекmpompancnopma. (During the football matches, new pedestrian areas, free parking lots and new traffic circles for urban electric transport will be arranged in Volgograd).

The analysis shows that the dominant in building up branding of modern Volgograd is its history and the events of the Stalingrad Battle. Numerous monuments that shape the identity of Volgograd speak for this.

The next one in frequency of text manifestations is information on the city's industrial potential what contributes to an image of economically developing region and a brand of a territory attractive for investments. That is true, that the city houses numerous operating industrial enterprises and companies which are an economic marker of the city's identity. Moreover, there is a tendency to rebranding in Volgograd, based on its economic and industrial attraction. A successful experience of rebranding of large industrial territories famous in the past time with their coal mining, metallurgical, textile, machine building manufacturing talks for the idea to develop one of the most populous regions in Russia - the Volgograd region, as a complex tourist destination.

The third dominant should be the event potential of the city, in particular, its sports component, especially, expecting the World Cup 2018.
Summarizing, we can conclude, that Volgograd demonstrates branding which depends on events arrangement. With the background of important historical events, the city builds a constant image of its heroic past, with the current events restricted with time dimension - an image of an active city.

Let us take a look at how Volgograd identity is depicted in the text of PowerPoint presentation presented in the web portal of Chemnitz - its partner city [http://www.chemnitz.de/chemnitz/de/die-stadtchemnitz/partnerstaedte/wolgograd/]. The translation text is pragmatically adapted and contains, together with the units corresponding to the source ones, inserted nominations determined by information fusion in the source text:

- das Verwaltungszentrum des Wolgograder Gebietes (the administrative center of the Volgograd region)

- eine der längsten Städte Russlands (one of the longest cities in Russia)

- eins der größten Industriezentren im Süden von Russland und in der Wolga-Region insgesamt (one of the largest industrial centers of the South of Russia and the Volga River basin)

- das Kulturzentrum des Wolgograder Gebietes (the cultural center of the Volgograd region)

- eins der größten Industriezentren im Süden von Russland (a large industrial center of the South of Russia)

- ein bedeutendes Sportzentrum (an important sports center).

We should consider an official character of the presentation and its emphasized neutrality, and also the absence of the most commonly used nomination of Volgograd - hero-city in the text addressed to modern German audience. However, the similar presentation texts about Volgograd are well represented in Internet and the above-mentioned nominations in a neutral manner and almost ordinary present one of the 15 cities with a million-plus population in Russia. The information portal of Chemnitz presents another text similar to the abovementioned info from the website of the city's administration [http://www.chemnitz.de/chemnitz/de/die-stadtchemnitz/partnerstaedte/wolgograd/].

This text in the German language created in the stylistics of the website includes efficient sociopragmatic comments and nominations with estimation of Volgograd:

- Die wechselvolle Geschichte der Stadt spiegelt sich in besonderer Weise in ihren verschiedenen Namen wider (The city's turbulent history is reflected in a particular manner in its different names).

- Heute ist Wolgograd eine aufstrebende Metropole und ein bedeutendes industrielles Zentrum SüdRusslands (Today, Volgograd is a developing metropolis and a large industrial center of the South of Russia).

The volume of adjectives with positive connotation in almost each sentence is 1500 signs (vielseitig, gigantisch, intensiv, weltbekannt, gewaltig, interessant, etc.), which reflects the general setup of the information portal for a positive image of the partner city - Chemnitz. This 
variant of communicative and pragmatic translation illustrates a trend principle in creation of translation text as a locally centered communication tool.

\section{Conclusion}

The linguistic analysis of branding as a communicative process aimed at maximum thorough and efficient use of the region's identity in provision of its attraction and also defining the functional features of the means of language used in urban discourse and estimation of the urban semiosis quality let talk for great importance of nominative and textual forms of the city's identity representation. Linguosemiotic signs explicating the city's identity play a leading role on creation of the text content aimed at increasing the attraction of the city as a tourist object, reveal its uniqueness for the representatives of its "own" and "foreign" cultures. The study of linguosemiosis in urban discourse shall let optimize the strategies of branding which goal is to create and fix positive images of the city and attractive representation of a global-centred and locally original territory.

The reported study was funded by the Russian Foundation for Basic Research (RFBR), the Administration of the Volgograd Region, Project No. 17-14-34001 Regional Tourism as Factor of Discourse and Translation Technology Formation: Nominative and Communicative-Pragmatic Conventions of Branding Texts (Volga Lands in the History and Culture of Russia 2018 Regional Contest, Volgograd Region)

\section{References}

1. S. Anholt, Place Branding and Public Diplomacy 6(1), 1-10 (2010)

2. G. Ashworth, M. Kavaratzis, Towards effective place brand management: Branding European cities and regions (Edward Elgar Publishing, Cheltenham, UK, 2010)

3. N.S. Dyagileva, The theoretical aspects of urban identity, Branding of small and middle-sized cities in Russia: practice, problems, perspectives (UrFU, Ekaterinburg, 2013)

4. F. Tennis, Community and society (Moscow, 2012)

5. G. Zimmel, Big cities and spiritual life (Moscow, 2002)

6. E.A. Yakovleva, Vestnik of Lobachevsky University of Nizhni Novgorod 6(2), 771-774 (2011)

7. N.V. Lyubimova, Vestnik of Moscow State Linguistic University 18 (624) (2011)

8. Yu.M. Lotman, Semiosphere (Iskusstvo-SPb, SaintPetersburg, 704, 2000)

9. V.A. Mityagina, E.Yu. Novikova, T.Yu. Makhortova, I.D. Volkova, Education and Humanities Research (ASSEHR) 97. Proceedings of the 7th International Scientific and Practical Conference "Current issues of linguistics and didactics:
The interdisciplinary approach in humanities" (CILDIAH 2017), Volgograd, 10-12 May, 320-325, (2017)

10. A.A. Gureeva, T.S. Sidorovich, A.A. Novozhilova, Education and Humanities Research (ASSEHR) 97. Proceedings of the 7th International Scientific and Practical Conference "Current issues of linguistics and didactics: The interdisciplinary approach in humanities" (CILDIAH 2017), Volgograd, 10-12 May, 274-279, (2017)

\section{Sources}

1. Official website of Volgograd administration [Ofitsyalny sayt administratsyy Volgograda] URL: http://www.volgadmin.ru/d/list/news/admvlg (date of access: 17.02.18)

2. Chemnitz Stadt der Moderne, URL: http://www.chemnitz.de/chemnitz/de/die-stadtchemnitz/partnerstaedte/wolgograd (date of access: 20.02.18) 